\title{
$[1]$
}

\section{The Argument of the Book:}

\section{Medieval Writing and Modern Theory}

You have extended like a skin the firmament of your Book [ $\mathrm{Li}$ ber], your harmonious discourses, over us by the ministry of mortals. . . . Let the angels, your supercelestial people, praise your name. They have no need to look upon this firmament, to know through reading your word. For they always see your face, and read there without the syllables of time your eternal will. They read, they choose, they love. They are always reading . . . the changelessness of your counsel.

Augustine, Confessiones

Reading "without the syllables of time" from a heavenly Book may have been recognized by most medieval students as an exclusively angelic privilege, one that contrasted rather obviously with the human activity of poring over the texts of the everyday world. Yet as Augustine assumes a distinction between heavenly and worldly books, his own passage illustrates the value of meditating on their similitude, and his procedure corresponds perfectly with the broad exhortation of the fathers of the church who instructed medieval readers to clarify and explain the mysterious purpose of the divine Word within the revealed words of this world, such as the Bible and the Book of nature. A far more vivid sense of the gap between human writing and transcendent language is customarily noticed in the works of writers many centuries after Augustine, for instance, in seventeenth-century authors like Sir Thomas Browne:

Thus there are two bookes from whence I collect my Divinity; besides that written one of God, another of his servant Nature, that universall 
and publik Manuscript, that lies expans'd unto the eyes of all; those that never saw him in the one, have discovered him in the other. . . Surely the Heathens knew better how to joyne and read these mysticall letters, than wee Christians, who cast a more carelesse eye on these common Hieroglyphicks, and disdain to suck Divinity from the flowers of nature.'

While the divine plan is rather less accessible to Browne's audience than it was to Augustine's, the exhortation is still to apprehend that order by reading it "as a book" - "that universall and publik Manuscript."

Both Augustine and Browne, notwithstanding their separation by many centuries, illustrate a similar problem: on the one hand they recognize the limitations of writing and reading within the "syllables of time," and on the other they conceive of nature and history as an order summarized in the metaphor of the perfect Text or Book. Although these examples manifest a clear distinction, the consequences of blurring or erasing it would eventually attract theoretical speculation in the history of discussions about writing - and rarely with more intensity than in recent theoretical debate about reading the institutions of culture "as a book." Not unlike Augustine, the father of modern semiology - Ferdinand de Saussure-recommends reflecting on the linguistic sign as a model for analyzing the structure of cultural forms, and his program for explaining the "language" of culture, at least as it has influenced Claude Lévi-Strauss's study of archaic societies, is no less expansive in theory than some of the medieval efforts to explain the semiology of the Book of nature. But against the structuralist request to study culture "as a book," the reminder of its abiding difference from the more limited written means of its construction has also been unmistakable in a number of poststructuralist works. For instance, with this difference in mind, the problem of periodization in history has been reopened, and modern conceptions of eighteenth- and nineteenth-century Europe have been shown to be modeled on the organicism of a text unified by singleness of purpose or ideology. ${ }^{2}$ And what may be true of a historical period, it is suggested, may also apply to the history of an entire discipline, like the history of Western literature or philosophy or art. The expo-

'Sir Thomas Browne, Religio Medici and ther Works, ed. L. C. Martin (Oxford: Clarendon Press, 1964), p. 15.

'See Hayden White, Metahistory: The Historical Imagination in Nineteenth-Century Europe (Baltimore: Johns Hopkins University Press, 1973); and idem, Tropics of Discourse: Essays in Cultural Criticism (Baltimore: Johns Hopkins University Press, 1978). 
sure of the organicism and teleology underlying such formulations of the past - their "textuality" - is too far removed from medieval and renaissance approaches to the problem to justify an attempt at demonstrating historical influence or continuity.

But while the problem of textuality in modern theory is involved with historical forces specific to the twentieth century, the debate about the ambiguity of the fading boundary line between text and written discourse has bearing on Augustine and his immediate intellectual heirs during the middle ages. For it is not at all clear that Augustine's separation of transcendent writing from the "syllables of time" was always preserved in his own works or in those of the writers who followed him. Nor is it obvious how the tradition of ideas concerning writing in the middle ages established the grounds for its own continuity or why departures from the tradition have customarily been located long after the waning of the middle ages in authors like Sir Thomas Browne or still later in modern criticism interested in "deconstructing" textuality. The project of deconstruction, to be sure, offers a graphic departure from the medieval evidence of textuality; but if a poststructuralist perspective may help us see medieval ideas in a way that has not heretofore been possible, the discussions about writing in the middle ages may very well turn out to confront modern deconstruction with its own history.

However, before considering any changes in the history of medieval textuality, it will be worthwhile first to turn to the grounds of its continuity. A useful starting point is provided by Jacques Derrida, since his distinction between "writing" (écriture) and the "idea of the book" suggests a certain resemblence to medieval discussions of writing and the Bible. Whereas the Text or Book has been regarded as a fact of literary history or a container of information and signs, Derrida has called attention to its function as a sign itself of a sense of meaning as homogeneous, present as a totality. On the other hand, as the means that strives to render that totality of meaning intelligible, "writing" (écriture) does not embody this conception of the Book and is essentially different from it: "the idea of the book, which always refers to a natural totality, is profoundly alien to the sense of writing. It is the encyclopedic protection of theology . . . against the disruption of writing, against its aphoristic energy, and . . . against difference in general." ${ }^{3}$ The idea of the

${ }^{3}$ De la grammatologie (Paris: Minuit, 1967), pp. 30-31; trans. Gayatri C. Spivak as Of Grammatology (Baltimore: Johns Hopkins University Press, 1976), p. 18. Paul Zumthor has traced a similar distinction between écriture and textual models in medieval French literature in his Essai de poétique médiévale (Paris: Seuil, 1972), and 
Book readily corresponds to the medieval conception of the Bible, the book that revealed or made present God's transcendent and absolute will, law, and wisdom, a container of the divine plan and itself a sign of the totality of that plan in the world. This idea of the Bible was composed from the familiar practice of reading "allegorically" for historical continuities between various scriptural books, such as King David as a type in the Old Testament of Christ in the New; of reading "tropologically" for moral significance, for example, David's adultery as representative of lechery and other deadly sins; and of interpreting "anagogically" for revelation of divine mysteries, such as David playing the psaltery as a prefiguration of the music accompanying the songs of the heavenly host in praise of the celestial lamb. ${ }^{4}$ Such assumptions of continuity and unity gradually led to the conception that any book of the Bible, or all of them together, constitutes a totality, not a loose collection of texts, but a book bound by a single purpose, which Saint Augustine called "the New Law of Charity." What Thomas of Celano said in the thirteenth century of the Book of Apocalypse was the implied understanding of the Bible from writings of the earliest fathers of the church. Apocalypse, said Thomas, "is the book in which the total is contained" ("Liber . . . in quo totum continetur"). ${ }^{5}$ In its simplest form, the idea of the Book begins in medieval readings of the Bible.

On the other hand, "writing" as écriture in the sense described by Derrida appears to have little place in medieval theories of language, since education was devoted to teaching that writing was not an arbitrary collection of words, but special, "divine" words whose "signifying" (signans) was not truncated from "signified" (signatum)

\footnotetext{
Eugene Vance has traced it in Augustine's works; see "Augustine's Confessions and the Grammar of Selfhood," Genre 6 (1973):1-28; "Augustine's Confessions and the Poetics of the Law," MLN 93 (1978):618-634; "Saint Augustine: Language as Temporality," in Mimesis: From Mirror to Method, Augustine to Descartes, ed. John D. Lyons and Stephen G. Nichols, Jr. (Hanover, N.H.: University Press of New England, 1982), pp. 20-35.

${ }^{4}$ For example, see Hugh of St. Cher, Opera omnia, 8 vols. (Venice, 1732): type of Christ (1 Kings 16), 1.231; adultery (2 Kings 11), 1.250; music ("Prologue" to Psalms), 2.2.

${ }^{5}$ Augustine, De doctrine Christiana 3.10; trans. D. W. Robertson, Jr., as On Christian Doctrine (New York: Bobbs-Merrill, 1958) , pp. 87-89; Thomas of Celano Dies irae, in Hymns of the Roman Liturgy, ed. Joseph Connelly (Westminister, Md.: Newman Press, 1957), p. 254, lines 13-15. Abundant references to the book are available in Ernst Robert Curtius's "The Book as Symbol," in European Literature and the Latin Middle Ages, trans. Willard R. Trask (New York: Harper \& Row, 1963), pp. 302347.
} 
allegorical, tropological, and anagogical truth. The "aphoristic energy" of writing did not oppose these correspondences, but linked them in an intricate system of revealing divine truth. What looked "different" in the Old Testament was simply a "prefiguration" of the New. From the medieval point of view, in other words, the literal sense of Scripture was hardly écriture, particularly as this term has been explained in recent critical debate with reference to the story of the discovery of writing told in Plato's Phaedrus. As Socrates relates the story, King Thamus repudiates Thoth's invention of writing because it is merely a "semblance" of truth that would impede the capacity to know and recall. "For this discovery of yours [writing] will create forgetfulness in the learner's souls, because they will not use their memories.... As for wisdom, it is the reputation [semblance], not the reality, that you have to offer to those who learn from you." ${ }^{\circ}$ While medieval instructors surely appreciated the distinction between "reality" and "semblance"-between Augustine's eternal Text and temporal writing - they nonetheless tried rigorously to locate divine wisdom within the letters of the $s a$ cra pagina. Instead of a stumbling block to truth, the "semblance" was its "revelation" in the Bible, the "veil" (integumentum) or "mirror" (speculum) in which divine wisdom was present, if only readers had "eyes to see." Writing in the middle ages corresponded closely to what Plato said about the "writing" in the soul. Derrida has commented on this point: "As was the case with the Platonic writing of the truth in the soul, in the Middle Ages too it is a writing understood in the metaphoric sense, that is to say a natural, eternal, and universal writing, the system of signified truth. ... As in the Phaedrus, a certain fallen writing continues to be opposed to it. There remains to be written a history of this metaphor, a metaphor that systematically contrasts divine or natural writing and the human and laborious, finite and artificial inscription."

In this remark the "divine or natural" writing of the middle ages is itself a metaphor of the "system of signified truth." Sir Thomas Browne's "publik Manuscript" and "letters" of nature repeat metaphors familiar in medieval books; he invites reading in the old medieval way the "letters," written or natural, as metaphors of divinity: the biblical tablets are "written with the finger of God" (Exod.

${ }^{6}$ Phaedrus, $275 \mathrm{AB}$, in The Dialogues of Plato, trans. Benjamin Jowett, $4^{\text {th }}$ ed. (Oxford: Clarendon Press, 1953), 3:184. See Jacques Derrida, "La Pharmacie de Platon," in La Dissémination (Paris: Seuil, 1972). Medieval sign theory is treated in detail below, chapter 3 .

${ }^{7}$ De la grammatologie, p. 27 ; trans. p. 15 . 
31.18), his "tongue" is a "pen" (Ps. 45.2), and the "heavens" are a "book" (Apoc. 6.14). Metaphorical transforming of eternal into natural is nowhere more vivid than in Isidore's metaphor of "plowshare" (vomer) for "stylus" (stilus) in the Etymologiarum:

\section{Vertamus vomerem}

In ceram mucroneque osseo.

[We turn the plowshare upon the wax, and plow with a point of bone. $]^{8}$

In other writers the field is a parchment, thorns are the scribes' errors, the plow is a pen, and letters are seeds. "Se pareva boves alba pratalia araba et albo versario teneba et negro semen seminaba" ("He urged on the oxen, plowed white fields, held a white plow, and sowed black seeds"). ${ }^{9}$ The "naturalizing" that turned a stylus into a plow and a line of writing into a furrow is only prefatory to the more elaborate exercises of the various books of beasts (bestiaries) in which any member of the animal world was "read" as a "sentence" or moral and eschatological truth. From the animal kingdom to the world of men, that naturalizing was carried over massively; as Alanus de Insulis observes, "every creature is a book":

Omnis mundi creatura

Quasi liber et pictura

Nobis est et speculum.

Universal history is a book of three stages for Hugh of St. Victor (lex naturalis; lex scripta; tempus gratiae); and all of nature is God's script - the Book of nature..$^{10}$ Learning to read the signs of that Book was a process not of "inventing" or "creating" sententia for the "sentences" in the Bible or nature, but of coming to comprehend a writing that exists "within a nature or a natural law, created or not, but first thought within an eternal presence. Comprehended, therefore, within a totality, and enveloped in a volume or a book. The idea of the book is the idea of a totality, finite or infinite, of the signifier; this totality of the signifier cannot be a totality, unless a totality constituted by the signified preexists it, supervises its inscriptions and its signs, and is independent of it in its ideality."

${ }^{8}$ Etym. 6.9.2 (PL 82, $\left.239 \mathrm{D}\right)$.

${ }^{9}$ Gerolamo Lazzeri, Antologia dei primi secoli della litteratura italiana (Milan: U. Hoepli, 1942), p. 1; cited in Curtius, p. 314 .

${ }^{10}$ Alanus, $P L 210,579$ A; Hugh, $P L$ 1 76, 32B, 343, 347, $371,644$.

${ }^{11}$ De la grammatologie, p. 30; trans. p. 18 . 
This summary by Derrida points to the inevitability of the "idea of the Book" in the middle ages as soon as a signifying systemwords in Scripture, things in nature-became a metaphor for divinity: the entire preexistent "totality" of God's plan was potential in the signifying means. Although Augustine began with a distinction between writing and the celestial Book, medieval reflections on the boundary line between them seem fascinated by the presence of one in the other. Master Theodoric, many centuries following Augustine, illustrates this fascination vividly in his painting of Matthew receiving the Divine Logos as a physical text; and Dante obviously meditated long and hard on this paradigm of writing, since he opened La vita nuova with the phrase "in that part of the book of my memory" and ended the Commedia with a vision of the cosmos as a magnificent volume whose "leaves are bound by love." 12 The cosmic Book was the ideal sine qua non of medieval architects, who imagined that they were copying it as vast encyclopedias in stone when they designed cathedrals across Europe and Britain from the eleventh century to the fourteenth. Like the relics of a saint in the cathedral, letters themselves were intrinsically sacred to Saint Francis of Assisi, who is said to have collected and saved every shred of parchment that he found during his travels because "litterae sunt quibus componitur gloriosissimum domini Dei nomen" ("letters are the things from which the most glorious name of God is composed"). ${ }^{13}$

Insofar as medieval evidence demonstrates that the metaphor of the Text, such as we find it in Augustine's Confessions (book 13), was extended throughout many aspects of the orders of nature and history, another important connection with modern theoretical dis-

\footnotetext{
${ }^{12}$ See plate 2. La vita nuova, in Le opere di Dante Alighieri, ed. E. Moore and P. Toynbee (Oxford: Oxf ord University Press, 1924), p. 205. La divina commedia, vol. 3, Paradiso (Firenze: Nuova Italia, 1957), 33.85-87, pp. 411-12.

${ }^{13}$ Thomas of Celano, Legenda prima, in S. Francisci Assisiensis vita et miracula (Rome: Desclée, Lefebure, 1906), p. 83. As will be discussed at greater length in chapters 2 and 3 , these kinds of examples suggest that medieval language theory leans much more heavily toward "logocentrism" than toward the deconstructive strategies that have been claimed for it, for example, by: Eugene Vance (note 3 above); Margaret W. Ferguson, "Saint Augustine's Region of Unlikeness: The Crossing of Exile and Language," Georgia Review 29 (1975):842-864; and Peter Haidu, "Repetition: Modern Reflections on Medieval Aesthetics," MLN 92 (1977):875-887.
} 


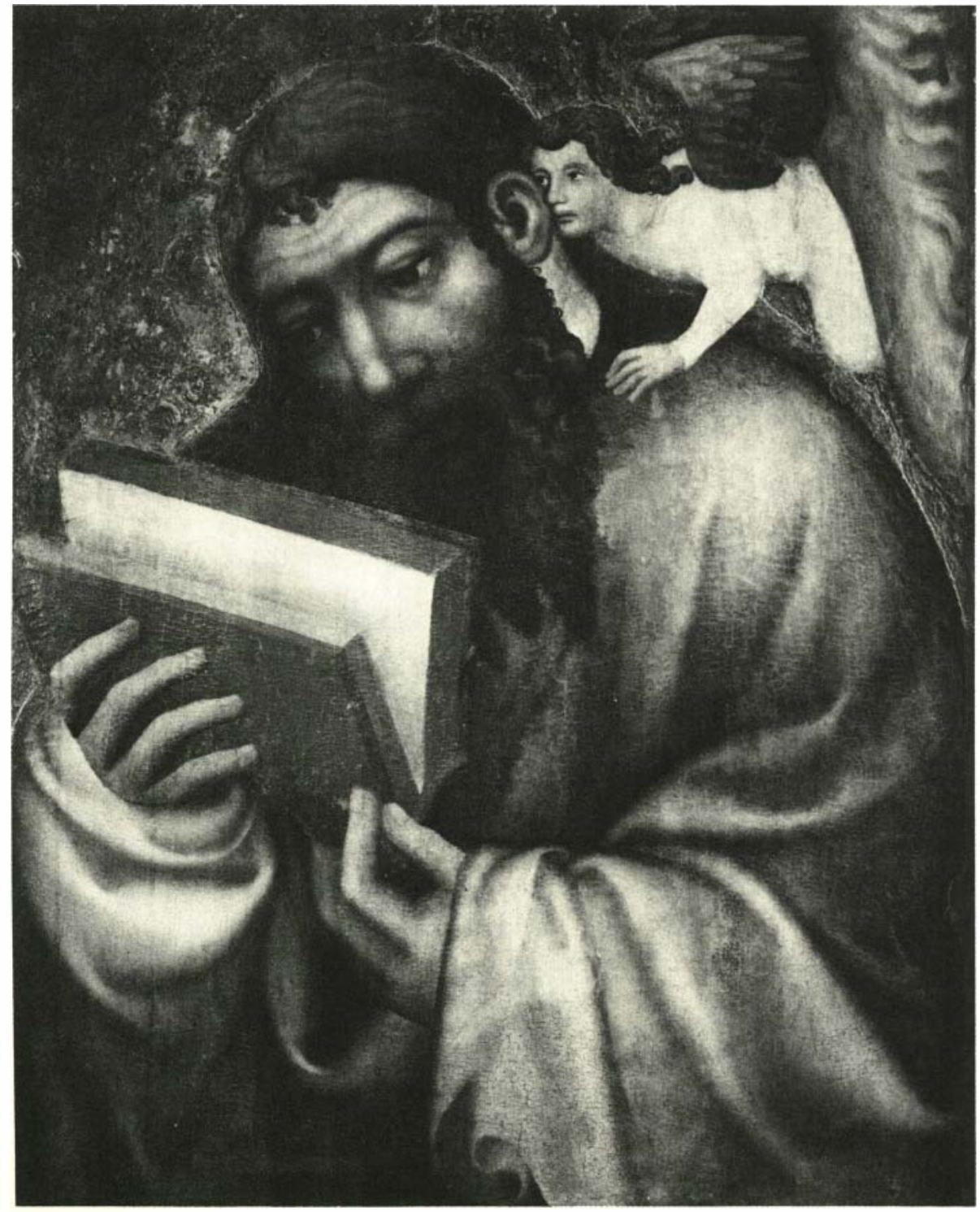

Plate 2. Matthew receiving the Word of God. Wooden panel. Master Theodoric (ca. 1360). Chapel of the Holy Cross, Karlstejn Castle. 
cussion of textuality presents itself for consideration - the relationship of the Book of culture and "myth." While this relationship may be noted in various quarters of scholarship, it has perhaps drawn most attention in studies of "mythological" cultures, for example, the primitive tribes analyzed by anthropologists or the societies of the archaic world (Ancient Egypt, Mesopotamia, Canaan, and Neolithic Europe). Initially it may appear that reference to a textual model for a culture in which writing was undeveloped or even unknown amounts to a rather willful use of terms. Yet the idea of the Book has served as an instructive model for reflecting on the nature of mythological forms, and it will also provide a helpful comparison in understanding patterns of thought in the middle ages. But, first, the term "myth" should not be confused with legends concerning special kinds of heroes, conflicts, settings, images, motifs, or themes. The term is used here in the anthropological sense defined by Georges Dumézil: "The function of that particular class of legends known as myths is to express dramatically the ideology under which a society lives; not only to hold out to its conscience the values it recognizes and the ideals it pursues from generation to generation, but above all to express its very being and structure, the elements, the connections, the balances, the tensions that contribute to it; to justify the rules and traditional practices without which everything within a society would disintegrate." 14

In the Phaedrus, Thoth's invention of writing is repudiated by King Thamus because he fears it will disintegrate "the very being and structure, the elements, the connections, the balances, the tensions" that constitute the culture. His mode of thought is "mythological" exactly because he fears that the "semblance" of writing will destroy wisdom and truth. That fear and his prohibition are indications of the determinations of mythological thought and its most distinguishing qualities: to identify a thought with a thing, to perceive the supernatural as immanent in the natural (a deity in a tree or stone), and to conceive of the divine realm as a replica of the physical order. In other words, as Sigfried Giedion has described Egyptian culture and its roots in prehistoric societies, mythological thought knows no "transcendent" world because it "sees" the eternal emanating throughout known and familiar things; stars, mountains, rivers, trees, caves, animals, and the elements of the earth are

${ }^{14}$ The Destiny of the Warrior, trans. Alf Hiltebeitel (Chicago: University of Chicago Press, 1970), p. 3 . 
intrinsically sacred, imbued with eternal truth and wisdom. ${ }^{15}$ Charting the continuities throughout the physical universe created elaborate systems of classification, such as those recorded in LéviStrauss's recent scholarship on South American mythology. Fire, thunder, stones, tools, crockery - any item or any event past or present could be connected in an elaborate network of related meanings. Myth was the comprehensive "encyclopedia" of a culture's several volumes - history, religion, physical science, and domestic lore - the unwritten Book of culture that was sacred by virtue of its embodiment of the eternal present in all things.

In such a world, writing is predictably received with suspicion or even hostility as a kind of trick, as King Thamus feared. For to represent truth by a written artificial means was to obscure its presence, if not offend the spirits of place, and to set up a barrier to the "true self" of wisdom emanating from stars to stones. Writing therefore not only was artificial, but even threatened to erode knowledge and desacralize divinity. King Thamus's prohibition was nothing less than a defense of the mythological consciousness. It may be compared with a more recent defense of mythological habits by a tribesman who also associates writing with forgetfulness and false knowledge. In contrast, his own learning is a direct participation in the continuity that simply knows no distinction between animal and human but assumes the natural oneness of the universe.

We know what the animals do, what are the needs of the beaver, the bear, the salmon, and other creatures, because long ago men married them and acquired this knowledge from their animal wives. Today the priests say we lie, but we know better. The white man has been only a short time in this country and knows very little about the animals; we have lived here thousands of years and were taught long ago by the animals themselves. The white man writes everything down in a book so that it will not be forgotten; but our ancestors married the animals, learned all their ways, and passed on the knowledge from one generation to another. ${ }^{16}$

Although this world may be appreciated conceptually, it seems very difficult to enter. From an alien viewpoint its knowledge is a

${ }^{15}$ The Eternal Present, vol. 2, The Beginnings of Architecture (New York: Bollingen Foundation, 1964), pp. 30-31, passim. See Henri Frankfort, "Myth and Reality," in Before Philosophy: The Intellectual Adventure of Ancient Man, ed. H. Frankfort, J. A. Wilson, and T. Jacobsen (Baltimore: Penguin Books, 1973).

${ }^{16}$ Cited in Claude Lévi-Strauss, The Savage Mind (Chicago: University of Chicago Press, 1969), p. 37. 
"lie"; yet from the mythological point of view the knowledge set down in writing is a dissembling aspect of a weak memory. But an understanding of writing as a metaphor of "divine or natural" perceiving, a "system of signified truth" - which is the writing that composed the medieval summa-resolves the opposition and establishes a direct link between myth and the Book. For the metaphor of writing does not get in the way of the truth with its "artificial inscription" and "difference" but reveals divine wisdom like a brilliant mirror (speculum). Writing is not conceived of as an invention superimposed on things; it is perceived "within a nature or a natural law, created or not, but first thought within an eternal presence. Comprehended, therefore within a totality, and enveloped in a volume or a book." Such a mode of "writing" is not écriture, but a system of supernatural knowledge determined by the preexistent assumption of the unity and totality - the eternal presence-of meaning. The metaphor of writing is the language of mythology, and the idea of the Book, like myth, is preoccupied with a oneness and continuity that it conceives of as natural. Insofar as the medieval conception of the Bible and the Book of culture illustrates the metaphor of writing, the two Books and the encyclopedias about them did not finally cut their ties with the mythological world they sought to repudiate. For the new activities of writing and reading carried with them traces of older mythological ways of perceiving: the idea of the Book that determined medieval writings was a new mythology.

In a certain respect, that the middle ages preserved ancient mythologies has been well known ever since sixteenth- and seventeenthcentury scholarship undermined archaic notions of the geocentric cosmos, the flat earth, the animism of nature, and attendant myths like magic, witchcraft, and demonology. "Mythography," more than any other discipline, preserved the few Greek and Roman legends, heroes, and motifs that were known, though not without changing them radically through Christian, most frequently tropological, interpretations in such works as Bernard Sylvester's Cosmographia (a commentary on Plato's Timaeus) and Pierre Bersuire's Ovidius moralizatus (an interpretation of the works of Ovid). Like the Christianizing of pagan sources in the middle ages, modern scholarship has assumed, to some extent, the medieval view of 
myth when the term describes a category including special kinds of figures, such as the deities in the story of Mars's love for Venus; or a class of themes, for instance, fertility in the Germanic and Celtic legends of the Fisher King; or a group of motifs, such as the quest for the Holy Grail in French and English sources. ${ }^{17}$ But the claim that the middle ages preserved mythological interests of the ancient world involves quite a different conception of "myth" as I have been using it, one that indicates particular habits of thinking, ordering, and remembering. Northrop Frye, for example, has pointed to such a sense of mythology in the middle ages by remarking that "in making so functional a use of astronomical imagery, and in seeing in the sky images of law, purpose, design, the cycle of the seasons, and the order of creation, as well as of fate and the source of tragedy, Chaucer is almost closer in mental attitude to the builders of Stonehenge than he is to us." 18

Although mythology may be reflected in certain kinds of images or narrative structures, Frye's remark indicates that it consists in a much broader perspective or "mental attitude" that may be called "mythologizing." The prehistorians Grahame Clark and Stuart Piggott have argued that such an attitude prevailed in the development of the middle ages: "It may not be extravagant to see an origin for much of medieval Europe in prehistoric societies which developed in the second millennium в.c." ${ }^{\prime 9}$ Mircea Eliade has shown that the forms of medieval Christian belief bear striking parallels with the "cosmic structure" of prehistoric mythology. Although European peasants, Eliade argues, were Christianized for over one thousand years,

they succeeded in incorporating into their Christianity a considerable part of their pre-Christian religious heritage which was of immemorial antiquity. It would be wrong to suppose for this reason European peasants are not Christians. But we must recognize that their religion is not confined to the historical forms of Christianity, that it still retains a cosmic structure that has been almost entirely lost in the experience of urban Christians. We may speak of a primordial, ahistorical

\footnotetext{
${ }^{17}$ For example, cf. Jean Seznec, The Survival of the Pagan Gods: The Mythological Tradition and Its Place in Renaissance Humanism and Art, trans. B. F. Sessions (1953; reprint, New York: Harper \& Row, 1961); D. W. Robertson, Jr., A Preface to Chaucer: Studies in Medieval Perspectives (Princeton: Princeton University Press, 1962); Brian Stock, Myth and Science in the Twelf th Century (Princeton: Princeton University Press, 1972).

${ }^{18}$ A Study of English Romanticism (New York: Random House, 1968), p.24.

${ }^{19}$ Prehistoric Socieities (New York: Alfred A. Knopf, 1965), p. 318.
} 
Christianity; becoming Christians, the European cultivators incorporated into their new faith the cosmic religion that they had preserved from prehistoric times. ${ }^{20}$

In any number of medieval books, summae, and encyclopedias like the Etymologiarum of Isidore of Seville, the De universo of Rabanus Maurus, and the Speculum majus of Vincent of Beauvais, we may find data that go back to prehistoric religion, such as the navel at the center of the world or the belief that the gods were once only men. But Eliade's claim that medieval Christians "incorporated" into their religion the "cosmic structure" of prehistoric myth corroborates the view that mythologizing determinations appear in the middle ages as part of the idea of the Book. The summae and encyclopedias may "contain" mythological material, but the Book itself is a sign of the mythologizing preoccupation with oneness, totality, and the presence of meaning as absolute.

Nowhere is this preoccupation clearer than in the massive classification, indexing, and subdivision of medieval encyclopedias. The following remarks in summary of Polynesian culture describe mythologizing preoccupations untouched by Christianity or writing, and yet they could stand as an introduction to the world of the great "books" of the middle ages, the Gothic cathedral, the Repertorium morale, De universo, Historia naturalis, the bestiaries, the Book of God's Word, and the Book of His Work.

All things - plants, animals, tools, man's social life, his rituals and the divine beings - are linked together in an intricate system of related meanings. The linkage is both genetic and static: everything has some connection with events going back to creation; and everything is bound to a system of parallel forms, of symbols - as, for example, the village is a human body; this body is also the primordial body of the first god; the house represents man's pedigree back to the gods; even pots are images of the universe. Further, this primitive Great Design is a definition and justification of human conduct; the same elaborately integrated system of symbols defines the significance of human life. ${ }^{21}$

This world of mythologizing thought unmarked by the "artificial inscription" of the written word is just as much a "Book" as the

${ }^{20}$ The Sacred and the Profane, trans. Willard R. Trask (New York: Harper \& Row, $1961)$, p. 164 .

${ }^{21}$ Robert Redfield, "Thinker and Intellectual in Primitive Society," in Culture in History: Essays in Honor of Paul Radin, ed. Stanley Diamond (New York: Columbia University Press, 1960), p. 8. 
writings that composed the medieval summa. Not only would a page of commentary from a work like the Great Glossa of the fourteenth century or the Opera omnia of Hugh of St. Cher in the thirteenth explain the linkage from past to present; exegesis would also replicate it in the process of quoting from "old authors" throughout the centuries-Augustine, Jerome, Cassiodorus, Gregorius Magnus, Bede, and others. Moreover, the repetition of this continuity in parallel forms is obvious in studies of past epochs like Peter Comestor's Historia scholastica and histories of the natural world like the works of Isidore, Rabanus, and Vincent of Beauvais. That the totality they attempted would eventually suggest a "house," a "city," or the "body of man" was ineluctable in imaginative writers like Augustine, who said that Eve was made from Adam so that the entire human race would be descended from the body of one man, or Hugh of St. Victor, who referred to the completeness and unity of Sacred Scripture as the domus Dei. ${ }^{22}$

What Durandus of Mende attempted in his massive thirteenthcentury commentary on the liturgy and architecture of the church was an extrapolation of patterns and meanings already immanent in the structure of the building; for it embodied the great design of the universe as a system of divine truth to instruct moral conduct and reveal the eschatological pains of hell and glories of heaven. As Durandus's book attempts to mirror in its subdivision and inclusiveness the design of the church, certain items in his book, or in other summae for that matter, reflect the whole in which they are included. The image of man as the microcosmus functions in this way in many medieval books, but it is hardly unique to them. Certain images in archaic cultures serve much the same function as mirrors of the subdivision and classification that characterize a larger mythology. For example, Lévi-Strauss records the Osage myth of the "pan-symbolic function" of the elk, "whose body is a veritable imago mundi: its coat represents grass, its horns hills, its flanks plains, its backbone the skyline, its neck valleys and its antlers the whole hydrographic network."

This and other parallels to medieval forms, however, do not reduce them to "primitiveness," but show rather that systems of classification in myth, as Lévi-Strauss has also pointed out, are as intri-

\footnotetext{
${ }^{22}$ Augustine: "quando nec ipsam quidem feminam copulandam viro, sicut ipsum creare illi placuit, sed ex ipso, ut omne ex homine uno diffunderetur genus humanum"; De civitate Dei 12.21 (PL 41,372D). Didascalicon 6.1, 2, and $4(P L 176$, $799,802)$; Hugh's figure is based on Gregorius Magnus, Moralium libri ( $P L{ }_{75}$, $513 \mathrm{C})$.
} 
cate as any page of Bersuire or Vincent of Beauvais. For instance, primitive herbal classifications

are evidence of thought which is experienced in all the exercises of speculation and resembles that of the naturalists and alchemists of antiquity and the middle ages: Galen, Pliny, Hermes Trismegistus, Albertus Magnus. . . . From this point of view "totemic" classifications are probably closer than they look to the plant emblem systems of the Greeks and Romans, which were expressed by means of wreaths of olive, oak, laurel, wild celery, etc., or again that practised by the medieval church where the choir was strewn with hay, rushes, ivy or sand according to the festival. ${ }^{23}$

This similarity between medieval and "totemic" classification is hardly coincidental; both are expressions of a common perspective that "reads" existing phenomena as connected by a preexistent design and then catalogs and indexes from a seemingly unquestioned sense of the unity and continuity of the universe: "The savage mind totalizes," Lévi-Strauss explains; it illustrates an "intransigent refusal . . . to allow anything human (or even living) to remain alien to it." ${ }^{24}$ While obviously very different in many ways from mythology, the writing that created the idea of the Book in the middle ages did not completely sever its link with mythologizing thought, for it "totalized" when it refused to allow anything living or even dead to remain unexplained by traditional ideology.

From one point of view, the survival of mythologizing is entirely predictable in geographical areas that during the middle ages were barely touched by cultural advances. But that it survived at all and even thrived simultaneously with the study of the Bible remains clearly paradoxical in light of the opposition of scriptural writing to mythology. That opposition, biblical scholars indicate, signals the gradual shift in the ancient Near East away from mythological religions of immanentism and toward Hebrew conceptions of divine transcendence. ${ }^{25}$ One obvious voice of that opposition is the familiar prohibitions against images heard in various biblical passages. For a divinity found through images, Jeremiah proclaims (10.1415), is no different from the gods of the Egyptians and Mesopotamians; but before the God of the heavens, "all men stand stupefied, uncomprehending, every goldsmith blushes for the idol

${ }^{23}$ Savage Mind, pp. 59, 42.

${ }^{24}$ Ibid., p. 245.

${ }^{25}$ For example, see William Foxwell Albright, Yahweh and the Gods of Canaan: An Historical Analysis of Two Contrasting Faiths (New York: Anchor, 1969). 
he has made, since his images are nothing but delusion, with no breath in them. They are Nothing, a laughable production." ${ }^{26}$ Yet while such denunciations must have sounded from the pulpits of the middle ages, the populace was charmed by an irresistible fascination with the images created by goldsmith, sculptor, and painter. The protest stands in relation to a cathedral rich with iconography in the same way that the écriture of Scripture was subsumed within the system that resolved its opposition and difference. As long as the idea of the Book prevailed against its écriture, mythology knew no threat in medieval culture. A challenge to it could not come, so to speak, from the "inside."

However, if the idea of the Book is perpetuated in a sense of writing as a metaphor of the "system of signified truth," then what about writings that are created and read in full acknowledgement that they are only a "semblance," a self-conscious invention? Does the writing of medieval fictions replicate or oppose the Book of culture? The answers to these questions must await close study of specific works. But a beginning may be made by comparing the idea of the Book with a few basic thoughts about the nature of fiction.

First of all, no one would argue that Chaucer's story of the pilgrimage to the shrine of Thomas à Becket, the long theological and philosophical debates in Le Roman de la rose, and Dante's journey from hell to heaven challenge the moral values of the Bible and Christian interpretations of it. Instead, the comprehensiveness alone of some medieval poems, like the Commedia, has suggested such comparisons to the encyclopedias and summae as the comment by Ernst Curtius that "Dante's cosmic poem is such a summa too." ${ }^{27}$ Evidence of this kind might lead one to the conclusion, which has in fact been drawn, that medieval fiction is not different from the writing in the Bible and that it too is a speculum, like the Book of God's Word and the Book of His Work..$^{28}$ The conclusion seems almost inevitable for a culture that saw sacred writing as the

${ }^{26}$ The Jerusalem Bible, ed. Alexander Jones (Garden City, N.Y.: Doubleday, 1966), used throughout unless otherwise noted.

${ }^{27}$ European Literature, p. 326.

${ }^{28}$ See D. W. Robertson, Jr., "Historical Criticism," in English Institute Essays, 1950, ed. Alan S. Downer (New York: Columbia University Press, 1951), pp. 3-31; idem, Preface to Chaucer, pp. 286-391; Robert Hollander, Allegory in Dante's Comedy 
actual inscription of "God's finger" and nature as a "script" of his will. Furthermore, instructions for reading the images and events of the Bible according to the divisions between the "literal" and "spiritual" senses are commonly cited as the rules for reading poetry in such works as the "Letter to Can Grande della Scala," attributed to Dante, and Boccaccio's Genealogia deorum gentilium, books 14 and 15 . Here we are told to study the obscurities in poetry according to the same rules for interpreting an event like the Exodus from Egypt - first as a historical occurrence; second as a moral deliverance of the soul from the bondage of sin; and last as a prefiguration of the passage of the soul from this life into the eternal paradise. As these intentions of the author of Holy Writ are not easily understood, neither are the meanings of poetry readily apparent; therefore, according to Boccaccio, "I repeat my advice to those who would appreciate poetry, and unwind its difficult involutions. You must read, you must persevere, you must sit up nights, you must inquire, and exert the utmost power of your mind. If one way does not lead to the desired meaning, take another; if obstacles arise, then still another; until, if your strength holds out, you will find that clear which at first looked dark. For we are forbidden by divine command to give that which is holy to dogs, or to cast pearls before swine." ${ }^{29}$ Confronted with an obscure text in the Commedia, The Canterbury Tales or Le Roman de la rose, a medieval reader might be able to find some encouragement in these words and might even discover that the "pearls" of his author corresponded with the moral values in Sacred Scripture. But that the passage or other arguments in the Genealogia confirm an identity between fiction and Holy Writ is debatable.

For no matter how useful the methods of scriptural reading are for poetry - and they have been shown to be profoundly fruitful-neither Boccaccio, Dante, Chaucer, nor any other medieval poet would say that his fiction was "divine" in origin. It might be inspired by the Holy Spirit, but it certainly would have been honestly recognized as an invention of more humble origins, as is clear even in the title of Dante's Commedia, which was not called "Divine" until the renaissance. The literal sense of Scripture, moreover, was understood as a record of documentary fact; it was historically true.

(Princeton: Princeton University Press, 1969); John V. Fleming, The "Roman de la Rose": A Study in Allegory and Iconography (Princeton: Princeton University Press, 1969).

${ }^{29}$ Boccaccio on Poetry, trans. Charles G. Osgood (New York: Liberal Arts Press, 1956), p. 62. 
But does Dante ask us to believe that he actually took a journey through the afterlife and, like Lazarus, has returned from the dead to tell all? His expectations of our response must be that we will have more detachment from the illusions he has created than his own fictional creations, for example Paolo and Francesca, who were seduced into the world of adulterous love while reading the myth of Lancelot and Guinevere.$^{30}$ Such "reading episodes" are far more potent than a palinode, insofar as they suggest that Dante would have us read his Commedia with the full self-consciousness of its status as an invention or a semblance. As Paolo and Francesca are seduced by the Book, Amant in the Roman is so enthralled by his dream of a rosy maiden that he knows not lady from flower until he embraces both as a stone statue in a castle wall. For one whose assent to the power of illusions is so absolute, a palinode of fers little salvation.

Because the representation of illusions may result in misguided responses, Dante and the poets of the Roman include in their works metapoetical arguments in the rules of adequate reading. But since even such arguments are themselves subject to interpretation, a more radical resolution may be imagined. For example, in the Republic Plato resolved the fear that fictions about the gods may readily distort true accounts of them by excluding from the utopia poets and poems that do not confirm public mythology. Although this decision might protect legends of the gods, it still does not solve the problem that poetry is by nature an illusion of a physical universe that is itself a copy of the world of perfect forms. Since poets present as true an "imitation and shadowy image," they are therefore "liars," and fiction is "true falsehood," which "is hated not only by the gods, but also by men."

Although we are admirers of Homer, we shall not admire the lying dream which Zeus sends to Agamemnon; neither will we praise the verses of Aeschylus in which Thetis says that Apollo at her nuptials

${ }^{30}$ Inferno, 5. The departure of fiction from the myth of the Book suggested here compares, in a certain respect, with Zumthor's argument about mouvance in medieval French literary tradition - the inevitable variations and transformations of an oeuvre like the Song of Roland into the many textes of individual performances of it: "L'oeuvre est fondamentalement mouvante. . . Le texte est la 'trace' de l'oeuvre: trace orale, fuyante, déformable," Essai, pp. 73, 74. Eugene Vance has also studied this departure in the Song of Roland; see Reading the "Song of Roland" (Englewood Cliffs, N.J.: Prentice-Hall, 1970); "Roland, Charlemagne, and the Poetics of Illumination," Oliphant 6 (1979):213-225; "Roland and the Poetics of Memory," in Textual Strategies: Perspectives in Post-Structural Criticism, ed. Josué Harari (Ithaca: Cornell University Press, 1979), 375-403. 
"was celebrating in song her fair progeny." . . These are the kind of sentiments about the gods which will arouse our anger; and he who utters them shall be refused a chorus; neither shall we allow teachers to make use of them in the instruction of the young, meaning, as we do, that our guardians, as far as men can be, should be god-fearing and godlike. ${ }^{31}$

The determination of medieval education to find the "godlike" meaning in the Bible seems to have fulfilled Plato's utopian hopes, insofar as it validated the public mythology and bound the Book of culture. But medieval poets clearly resented traditional objections to poetry, and in defending it against the charge of falsehood, apologists like Boccaccio went much further than Plato in separating fiction from truth. "The charge of falsehood," Boccaccio argues, "is without force, since poetic fiction has nothing in common with any variety of falsehood, for it is not a poet's purpose to deceive anybody with his inventions; furthermore, poetic fiction differs from a lie in that in most instances it bears not only no close resemblance to the literal truth, but no resemblance at all; on the contrary, it is quite out of harmony and agreement with the literal truth." 32 This passage grants the reader more trust in his own ability to distinguish fact from fiction than Plato ever would, perhaps because it describes the writing of the real world, not utopian writing that dares not offend known and familiar ideas, the spirits of place, and sacred lore. Such mythology is basically different from fiction, as Plato certainly feared. But poets of the middle ages, although they lived in a culture dominated by utopian ideals, assumed a more generous capacity in their audience for understanding their writing than was admitted in the system of supernatural writing that organized the Book of culture. Yet the assumption of a poet notwithstanding, one member of an audience, like the Reeve in Chaucer's Canterbury Tales, will inevitably rise up to confirm Plato's old fear by imagining that a fiction told by a Miller about domestic folly is a biography of his own marital embarrassments. The Reeve's "mistaken reading," like other acts in the "roadside drama," may exist not only for the values of good theater, but for the metapoetical purposes of recognizing the "facts" of fiction. ${ }^{33}$

\footnotetext{
${ }^{31}$ Republic, 2, in Critical Theory since Plato, ed. Hazard Adams (New York: Harcourt Brace Jovanovich, 1971), pp. 22-23.

${ }^{32}$ Boccaccio on Poetry, p. 63.

${ }^{33}$ See G. L. Kittredge, "Chaucer's Discussion of Marriage," MP 9 (1911-1912): 437-467; R. M. Lumiansky, Of Sundry Folk: The Dramatic Principle in the "Canterbury Tales" (Austin: University of Texas Press, 1955); R. M. Jordan, Chaucer and the Shape of Creation (Cambridge: Harvard University Press, 1967), pp. $121 \mathrm{ff}$.
} 
Such mistakes are explainable, in one sense, because they illustrate the controlled and conscious "mistake" every reader makes in willingly suspending disbelief in order to grant credibility to the claims of fiction. But fiction begins with and encourages the awareness of its illusion making. We cannot, however, say the same about medieval response to the Book of culture. For even though a chapter in that Book, such as Plato's Timaeus, might be qualified by its author as only "a likely story" of the $\operatorname{cosmos},{ }^{34}$ it was received with such authority in the middle ages that any sense of its "likeliness" fell away as the story grew into an elaborate mythology, lasting centuries beyond Bernard Sylvestris's thirteenth-century commentary on it. The Book of culture does not invite the sense of conjecture and hypothesis that is engaged in the reading of fiction. Rather, the Book of culture, like myth, leaves no doubt that it is a true account of the cosmos, history, nature, and the afterlife. Medieval fictions, in contrast, specialize in doubt, and while they also delight in religious values, they remain basically different from, if not opposed to, the myth of the book of culture.

The opposition consists in the recognition that Plato mentioned in the Phaedrus and the Republic and that is extended so clearly by Boccaccio: fiction creates illusions self-consciously and proceeds on the assumption that readers will not turn away complaining of its "lies." As Chaucer often described poetry, it is "pleye," and "men shall not not maken ernest of game." ${ }^{35}$ The play of poetry took the sacrality - the "mythology" - out of writing, preventing its growth into myth. The insistence on fixed and centered structure, one of the defining properties of mythology, is obvious in many medieval notions, such as the axis mundi, the navel at the center of the world, the geocentric cosmos, and the New Law of Charity (maintained as the organizing principle of every chapter and book of the Bible). But the play of medieval fictional writing refuses such fixity, plays with the location of the center, and accommodates its own deficiencies by making no mistake about its difference from the natural and supernatural orders. As écriture opposes the "idea of the Book" (according to Derrida's argument), fiction plays with those orders

\footnotetext{
${ }^{34}$ See the commentary by F. M. Cornford, trans. Plato's Cosmology: The "Timaeus" of Plato (New York: Bobbs-Merrill, n.d., orig. pub. 1937), pp. 28-32.

35" The Miller's Prologue," in The Works of Geoffrey Chaucer, ed. F. N. Robinson, 2d ed. (Boston: Houghton Mifflin, 1957), p. 48. The separation between the textual tradition and Chaucer's stress on the "pleye" of literature has been argued in a related way by Glending Olson, Literature as Recreation in the Later Middle Ages (Ithaca: Cornell University Press, 1982).
} 
that the Book of culture presents as absolute. ${ }^{36}$ While the medieval and modern oppositions have little in common (écriture is hardly equivalent to "fiction"), their ef fect on structure is similar, insofar as they both initiate processes of change. The "play" of poetry, be it in Chaucer, Dante, or the poets of the Roman, destabilized medieval mythology, as earlier "play-factors" in the culture-according to Johaı Huizinga - had changed cultural forms inherited from the ancient world.

For the Middle Ages had inherited its great culture-forms in poetry, ritual, learning, philosophy, politics, and warfare from classical antiquity, and they were fixed forms. Medieval culture was crude and poor in many respects, but we cannot call it primitive. Its business was to work over traditional material, whether Christian or classical, and assimilate it afresh. Only where it was not rooted in antiquity, not fed by the ecclesiastical or Graeco-Roman spirit, was there room for the playfactor to "play" and create something entirely new. That was the case wherever mediaeval civilization built directly on its Celto-Germanic past or on even earlier autochthonous layers. ${ }^{37}$

The form least tied to antiquity or the church - the one that is the unique creation of the middle ages - is its vernacular literature. No sooner had it emerged than it needed defenses, such as Dante's De vulgari eloquentia and Boccaccio's Genealogia, books 14 and 15 , not simply because it was different, but because its difference challenged the Book of culture just as other "play-factors" had changed the mythology of the Celto-Germanic past. Such a displacement was as inevitable as it was necessary, but that it was ushered in by fiction remains a paradox echoing in the nostalgia for the old world order in Sir Thomas Browne's invocation to read the "universall and publik Manuscript." For his text, like medieval fictions before it, also echoes with his own self-conscious play with

\footnotetext{
${ }^{36}$ For Derrida's comments on play (jeu) in relation to structure, see The Structuralist Controversy: The Languages of Criticism and the Sciences of Man, ed. Richard Macksey and Eugenio Donato (Baltimore: Johns Hopkins University Press, 1970), p. 268; and "La Pharmacie de Platon."

${ }^{37}$ Homo Ludens: A Study of the Play-Element in Culture (Boston: Beacon, 1955), p. 179. Cf. Eugene Vance: "We have every reason to examine [the] implicit models of communication [in the Song of Roland] for indications of disruption and change that might correspond to an epistemological crisis rooted in the competing cultural functions of speech and writing"; "Roland and the Poetics of Memory," in Textual Strategies, p. 401; Peter Haidu: "Fiction, even where intentionally established to function in subordination to an ideological superstructure, is inherently subversive of such vehiculation"; "Repetition," MLN 92 (1977):886.
} 
metaphor that necessarily changes the mythology it seeks to perpetuate.

Medieval fiction may have incorporated information from the summae and encyclopedias, but it did not replicate them. The play with metaphor in poetry stands in direct opposition to the metaphor of divine or natural writing that characterizes medieval readings of the Bible and nature. Books of fiction must be separated from the Book of culture. For that Book is the creation of medieval perspectives that have less to do with the Bible itself than with the mythologizing habits of mind that the Bible sought to undermine. In its difference from mythology, fiction compares with the Bible before medieval readings created an ideology for it and turned it into a myth of homogeneous doctrine. Fiction does not mythologize. Although medieval poets were educated in inherited mythologies, they begin - not unlike the critical spokespersons in the Bible - from the vantage point of reinterpreting their culture and often challenging its myths. The effect of their writing is to see the past and present from a different perspective, and that difference compares with the objectivity sought by scholars in the renaissance who wanted to separate themselves from medieval tradition by understanding the past in its own right before time put meaning upon it. Medieval fictions certainly brought about no Copernican revolution. But the difference of myth from fiction figures prominently in the separation of "Middle Ages" from "Renaissance": that this shift was well under way in nominalism and the development of empirical methods in physical science needs no affirmation; but the degree to which medieval fiction writing became the ground for important changes in the modes of signifying meaning remains to be probed. The mythology of the Book of culture, concerned as it is with resisting change by perpetuating past models, stabilizes the conception of history as a text of organically whole "periods." Augustine's temporal language disappears into the timeless writing of an angelic intelligence. But fiction asserts its difference by inviting our challenge, by presenting us with a demand for criticism and for theories about our criticism that test and question the ways we signify meaning - even as my own are doubtless being tested now. That demand offers an approach to cultural understanding that does not indict historical inquiry, but rather promises a new and enlightened historicism. 